\title{
Feeding habits of Cocobolo Andinoacara pulcher in the cienaga Grande de Lorica, Colombia
}

\author{
Hábitos alimentarios de Cocobolo (Andinoacara pulcher) en la \\ ciénaga Grande de Lorica, Colombia
}

\author{
Charles W. Olaya-Nieto, ${ }^{1}$ M.Sc, Liquey Camargo-Herrera, ${ }^{2}$ Prof. Acuicul, \\ Vanessa Díaz-Sajonero, ${ }^{2}$ Prof. Acuicul, Fredys F. Segura-Guevara, ${ }^{1 *}$ M.Sc.
}

\begin{abstract}
${ }^{1}$ Universidad de Córdoba, Faculty of Veterinary Medicine and Zootechnical Science, Department of Aquatic Sciences, Fisheries Biology Research Laboratory-FBRL. Cra 23 No. 2A-20, Piso 2. Lorica, Colombia. 2Universidad de Córdoba, Faculty of Veterinary Medicine and Zootechnical Science, Department of Aquatic Sciences, Aquaculture Program. Montería, Colombia. *Correspondence: ffsegura@correo.unicordoba.edu.co
\end{abstract}

\section{ABSTRACT}

Received: June 2014; Accepted: April 2015.

Objective. The feeding habits of Cocobolo (Andinoacara pulcher) in the cienaga Grande de Lorica, Sinu river basin, were studied. Materials and methods. The stomach content was analyzed using the Proportion of empty stomachs, Grade of digestion, Frequency of occurrence, numerical Frequency, Gravimetry, relative importance Index (RII) and the gut length-total length relationship. Results. $39.8 \%$ of stomachs were empty, $47.1 \%$ of preys were fresh and five food groups were identified. Vegetable remains was the most frequent group (63.8\%) and the prey with greatest composition in weight $(33.5 \%)$, while Rest of fishes was the most abundant group $(34.7 \%)$. It was observed that in low and rising waters, fishes was the most consumed prey, while that in high and falling waters the most consumed prey was vegetable remains. Vegetable remains, detritus and fishes were food groups of secondary relative importance, while Insects and Others were circumstantial or incidental groups. Conclusions. The results achieved indicate that Cocobolo is a fish with omnivores feeding habits with a preference for fishes and vegetable remains.

Key words: Diet, feeding, food preferences, trophic levels (Source: $C A B$ ).

\section{RESUMEN}

Objetivo. Se estudiaron los hábitos alimentarios de Cocobolo (Andinoacara pulcher) en la ciénaga Grande de Lorica, cuenca del río Sinú, Colombia. Materiales y Métodos. El contenido estomacal se evaluó con el Coeficiente de vacuidad, Grado de llenado, Grado de digestión, Frecuencia de ocurrencia, Frecuencia numérica, Gravimetría, Indice de importancia relativa y la relación longitud intestinallongitud total. Resultados. El 39.8\% de los estómagos se encontró vacío, el $47.1 \%$ de las presas en estado fresco y se identificaron cinco grupos alimentarios. Material vegetal fue el grupo más frecuente $(63.8 \%)$ y con mayor composición por peso $(33.5 \%)$, mientras que Restos de peces fue el más abundante (34.7\%). Se observó que en aguas bajas y en aguas ascendentes, peces fue la presa más consumida, mientras que en aguas altas y aguas descendentes, fue material vegetal. Material vegetal, detritos y restos de peces fueron grupos alimentarios de importancia relativa secundaria, mientras que insectos y otros fueron circunstanciales o incidentales. Conclusiones. Los resultados alcanzados indican que Cocobolo es un pez de hábitos alimentarios omnívoros con preferencia por peces y material vegetal.

Palabras clave: Alimentación, dieta, niveles tróficos, preferencias alimentarias (Fuente: CAB). 


\section{INTRODUCTION}

Cocobolo (Andinoacara pulcher) (1) is a small fish that has sedentary habits. The males are more colorful and larger than the females, and turn a more vibrant blue in the reproductive season.

In Colombia, they are found in the rivers of the Caribbean versant, including the Sinú river basin, as in the case of the Ciénaga Grande de Lorica, where it generally does not form part of the commercial fishery. However, both in the swamp as well as in the basin, it is an important component in the food chain, because it is one of the most consumed fish by large and small predators, such as Ariopsis sp. (2) and Rhamdia quelen (3), respectively.

Studies in other geographical areas of the country report that the species consumes worms, crustaceans, insects and live preys (4). On the Ciénaga Grande de Lorica, The length at first maturity is $9.5 \mathrm{~cm} \mathrm{LT}$, with prolonged spawning season that extends throughout the year with partial spawning of 954 oocytes (5).

The objective of this study was to determine the feeding habits of Cocobolo on the Ciénaga Grande de Lorica as a contribution to knowledge of its biology and ecology and its preservation in the environment and the management of their fishery in the floodplain and in the Sinú basin.

\section{MATERIALS AND METHODS}

Study area. This study took place in Ciénaga Grande de Lorica, a body of water located downstream from the Urrá dam, which has a maximum depth of 5 meters in the rainy season. Multi-year average rainfall reaches $1200 \mathrm{~mm}$ with a bimodal rainfall and an average temperature of $27^{\circ} \mathrm{C}$ from the study area to the coastal area of the Caribbean sea (6).

Obtaining samples. Musilová et al (1) was followed for species identification. 294 individuals were captured between January and December 2005, except in March, and total length ( $T L$ ) and standard length (SL) was measured to the nearest $\mathrm{cm}$ with a graduated measuring ictiometer (IK2, Aquatic Biotechnology, Spain) and total weight was measured (TW) with an electrical scale $5000 \pm 1 \mathrm{~g}$ (CS 5000, Ohaus Corporation, USA). The fish were caught with hook and line and castnet, kept cool in 51 liter polyurethane coolers (Cooler Camping 2A16, Rubbermaid, USA) and were transported to the Fisheries Biology Research Laboratory-FBRL of the Universidad de Córdoba in Lorica.

\section{INTRODUCCIÓN}

El Cocobolo (Andinoacara pulcher) (1) es un pez de tamaño pequeño y hábitos sedentarios, que se caracteriza porque los machos son más coloridos y más grandes que las hembras; acentuando su coloración azul en la época de reproducción.

En Colombia, ocurre en los ríos de la vertiente del Caribe, incluyendo la cuenca del río Sinú, como es el caso de la ciénaga Grande de Lorica, en donde presenta poca participación en la pesquería comercial. Sin embargo, tanto en la ciénaga como en la cuenca es un componente importante en la cadena trófica, porque es uno de los peces más consumidos por grandes y pequeños predadores como Barbul de piedra Ariopsis sp. (2) y Liso Rhamdia quelen (3), respectivamente.

Estudios realizados en otras áreas geográficas del país reportan que la especie consume gusanos, crustáceos, insectos y presas vivas (4). En la ciénaga Grande de Lorica, la talla media de madurez sexual es de $9.5 \mathrm{~cm}$ LT, con época de desove prolongado que se extiende durante el año con desoves parciales de 954 ovocitos (5).

El objetivo de este trabajo fue estudiar los hábitos alimentarios de Cocobolo en la ciénaga Grande de Lorica como contribución al conocimiento de su biología y ecología, a su preservación en el medio natural y al ordenamiento de su pesquería en la ciénaga y en la cuenca del Sinú.

\section{MATERIALES Y MÉTODOS}

Área de estudio. Este trabajo se realizó en la ciénaga Grande de Lorica, cuerpo de agua ubicado aguas abajo de la represa de Urrá, el cual presenta una profundidad máxima de 5.0 metros en épocas de lluvia. La pluviosidad alcanza valores medios multianuales de 1200 $\mathrm{mm}$, con un régimen bimodal de precipitaciones y la temperatura promedio es de $27^{\circ} \mathrm{C}$, incluyendo desde el área de estudio hasta la zona costanera del mar Caribe (6).

Obtención de las muestras. Se siguió a Musilová et al (1) para la identificación de la especie. Se capturaron 294 individuos entre enero y diciembre 2005, excepto en marzo, y se midió longitud total (LT) y longitud estándar (LS) al $\mathrm{cm}$ más cercano con un ictiómetro graduado (IK2, Aquatic Biotechnology, España) y el peso total (WT) con una balanza eléctrica de $5000 \pm 1$ g (CS 5000, Ohaus Corporation, USA). Los peces fueron capturados con la ayuda de artes de pesca como línea de mano y atarraya, refrigerados en neveras de poliuretano de 51 litros de capacidad (Cooler Camping 2A16, Rubbermaid, USA) para 
Stomach extraction. Following techniques used by Laevastu (7), the fish were dissected and different parts of the digestive tract were located. The stomach and intestines were then removed and stored in plastic bottles containing $250 \mathrm{ml}$ of buffered formalin at $10 \%$. All bottles were labelled to indicate species, sample number and date. The above mentioned information was recorded as well as the site of capture, fishing gear used, size, total weight and gutted weight.

Analysis of stomach content. Stomach content was placed in a Petri dish and was examined with a stereoscope (Leica Zoom 2000, Leica Microsystems $\mathrm{GmbH}$, Germany) and microscope (Leica CME, Leica Microsystems GmbH, Germany), separating, identifying and numbering the food or preys present. Identification was performed until the taxonomic level allow according to the degree of digestion of the food, organizing the information by items, preys or groups, and weighing them on an $1500 \pm 0.01 \mathrm{~g}$ electric scale (Adventurer, Ohaus Corporation, USA).

The emptiness coefficient (CV) was estimated as $\mathrm{CV}=100 *$ Number of empty stomachs / Total number de analyzed stomachs (8).

The degree of digestion (GD) was evaluated according to the state of fresh, partially digested and digested preys (7).

Three methods were used to quantify stomach contents, expressed in average monthly and annual values: frequency of occurrence (FO), numeric frequency (FN) and gravimetrics (G) (9).

$\mathrm{FO}=100 *$ Occurrence of preys from item A/Total number of stomachs with food.

$\mathrm{FN}=100 *$ Number of preys from item A/Total number of prey.

$G=100 *$ Weight of preys from item A/Weight of all prey.

To establish the importance of each prey in the diet, the modified relative importance index (RII) was estimated (10): RII $=\mathrm{F} * \mathrm{G} / 100$ where RII represents the relative importance index, $F$ is the frequency of occurrence percentage and $G$ is the weight percentage. This is expressed in a range from 0 to 100 , where 0 to $10 \%$ represents trophic groups with relatively low importance, 10 to $40 \%$ as relatively important and 40 to $100 \%$ as groups of relatively high importance.

The total length gut-length relation was established according to the Brusle scale (11) and food preferences were analyzed according to ser transportados al Laboratorio de Investigación Biológico Pesquera de la Universidad de Córdoba, ubicado en Lorica.

Extracción de los estómagos. De acuerdo con las técnicas de Laevastu (7), una vez efectuada la disección de los peces, se ubicaron las diferentes partes del tubo digestivo. Luego se procedió a retirar el estómago y el intestino para conservarlos en frascos plásticos de $250 \mathrm{ml}$ que contenían formol al $10 \%$ bufferado. Todos los frascos fueron rotulados, indicando la especie, número de la muestra y fecha. Se registró la información citada arriba más el sitio de captura, arte de pesca utilizao, talla, peso total y peso eviscerado.

Análisis del contenido estomacal. El contenido estomacal se colocó en una caja Petri y se examinó al estereoscopio (Leica Zoom 2000, Leica Microsystems $\mathrm{GmbH}$, Alemania) y microscopio (Leica CME, Leica Microsystems GmbH, Alemania), separando, identificando y enumerando el alimento o presas presentes. La identificación se efectuó hasta el nivel taxonómico permitido por el grado de digestión del alimento, ordenándose en ítems, presas o grupos, pesándose en una balanza eléctrica de $1500 \pm 0.01 \mathrm{~g}$ (Adventurer, Ohaus Corporation, USA).

El coeficiente de vacuidad (CV) se estimó con $\mathrm{CV}=100 *$ No. estómagos vacíos / No. total de estómagos analizados (8).

El grado de digestión (GD) se evaluó de acuerdo con el estado de las presas en Fresco, Medio digerido y Digerido (7).

Se utilizaron tres métodos para cuantificar el contenido estomacal, expresado en valores promedios mensuales y anuales: Frecuencia de ocurrencia (FO), Frecuencia numérica (FN) y Gravimetría (G) (9).

$\mathrm{FO}=100 *$ Ocurrencia de presas del ítem A/No. total de estómagos con alimento

$\mathrm{FN}=100 *$ No. de presas del ítem $\mathrm{A} / \mathrm{No}$. total de presas

$\mathrm{G}=100 *$ Peso de las presas del ítem A/Peso de todas las presas.

Para establecer la importancia de cada presa en la composición de la dieta se estimó el Índice de importancia relativa modificado (IIR) (10): IIR $=F^{*} G / 100$, en donde, IIR representa el Índice de importancia relativa, $\mathrm{F}$ es el porcentaje de la Frecuencia de ocurrencia y $G$ es el porcentaje gravimétrico. Esta expresión presenta un 
the sizes of the species under study and the water cycle of Ciénaga Grande de Lorica in seven class intervals (7.5-8.5 to $13.5-14.5 \mathrm{~cm} \mathrm{LT}$ ) and taking into account the classification used to define the four levels of Cienaga Grande de Lorica during its annual water cycle: low waters (December, January, February), rising waters (March, April, May), high waters (June, July, August) and falling waters (September, October, November).

Descriptive statistics were used, expressing variables as mean \pm standard deviation, and a correlation coefficient for the intestinal lengthtotal length relationship was estimated.

\section{RESULTS}

The minimum recorded size was $7.2 \mathrm{~cm}$ TL (March), the maximum was $14.5 \mathrm{~cm}$ LT (October and December) and the lowest weight was $9.1 \mathrm{~g}$ (March) and the highest $89.1 \mathrm{~g}$ (December). The frequency distribution for sizes showed a curve with ranges between 7.0 and $15.0 \mathrm{~cm}$ LT, and an average catch size of $10.7 \mathrm{~cm} \mathrm{LT}(n=294)$ that indicates that $17.3 \%$ of individuals were caught below the length at first maturity for both sexes as estimated by Olaya-Nieto et al (5), presenting sexual dimorphism in size given that males are larger than females. The frequency distribution for weight showed ranges between 10.0 and $90.0 \mathrm{~g}$, an average weight of $30.0 \mathrm{~g}$ and modal frequency at $20.0 \mathrm{~g}$.

$39.8 \%$ of stomachs studied were empty, especially in the months of March $(100.0 \%)$, November (70.0\%), December (64.3\%), February (56.5\%) and April (50.0\%), where the maximum values were reached. $47.1 \%$ of food consumed was fresh, $29.8 \%$ half-digested and $23.1 \%$ digested. As shown in figure 1, fresh prey was found in almost every month except March, when all stomachs were empty $(C V=100 \%)$, reaching highest monthly values except in

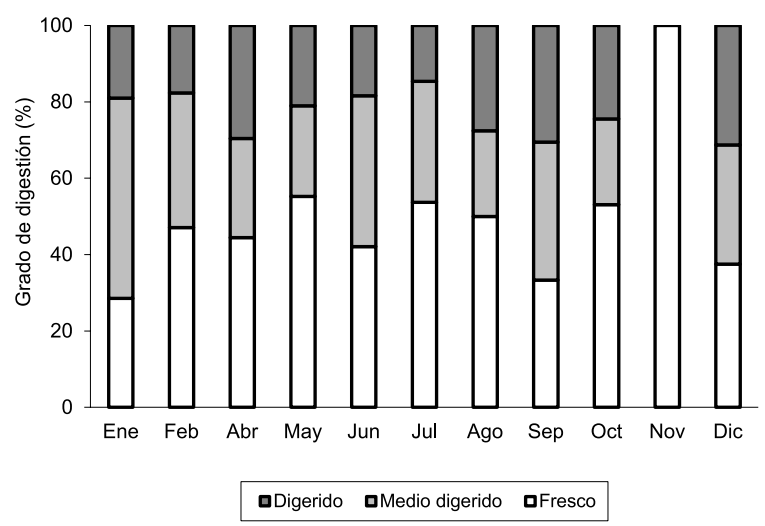

Figure 1. Degree of monthly digestion. rango de 0 a 100, en donde el rango de 0 a $10 \%$ representa grupos tróficos de importancia relativa baja, de 10 a $40 \%$ grupos de importancia relativa secundaria y 40 a $100 \%$ grupos de importancia relativa alta.

Se estableció la relación longitud intestinallongitud total de acuerdo con la escala de Brusle (11), y se analizaron las preferencias alimentarias de acuerdo con las tallas que presenta la especie en estudio y con el ciclo hidrológico de la ciénaga Grande de Lorica, conformándose siete intervalos de clase (7.5-8.5 a 13.5-14.5 cm LT) y teniendo en cuenta la clasificación utilizada para definir los cuatro niveles de la ciénaga Grande de Lorica durante su ciclo hidrológico anual: aguas bajas (diciembre, enero, febrero), aguas ascendentes (marzo, abril, mayo), aguas altas (junio, julio, agosto) y aguas descendentes (septiembre, octubre, noviembre).

Se utilizó estadística descriptiva, expresando las variables como media \pm desviación estándar y se estimó el coeficiente de correlación a la relación longitud intestinal-longitud total.

\section{RESULTADOS}

La talla mínima registrada fue de $7.2 \mathrm{~cm} \mathrm{LT}$ (marzo), la máxima de $14.5 \mathrm{~cm}$ LT (octubre y diciembre); mientras que el menor peso fue de $9.1 \mathrm{~g}$ (marzo) y el mayor de $89.1 \mathrm{~g}$ (diciembre). La distribución de frecuencias de tallas presentó una curva con rangos entre 7.0 y $15.0 \mathrm{~cm}$ LT, con talla media de captura de $10.7 \mathrm{~cm}$ LT ( $\mathrm{n}=294$ ), lo que indica que el $17.3 \%$ de los individuos fueron capturados por debajo de la talla media de madurez para sexos combinados estimada por Olaya-Nieto et al (5), observándose dimorfismo sexual a la talla, puesto que los machos son más grandes que las hembras. La distribución de frecuencias de pesos mostró rangos entre 10.0 y $90.0 \mathrm{~g}$, peso promedio de $30.0 \mathrm{~g}$ y frecuencia modal de $20.0 \mathrm{~g}$.

Del total de estómagos estudiados, el 39.8\% se encontró vacío, destacándose los meses de marzo (100.0\%), noviembre $(70.0 \%)$, diciembre (64.3\%), febrero (56.5\%) y abril (50.0\%), en donde alcanzó sus máximos valores. El $47.1 \%$ del alimento consumido estaba en estado fresco, $29.8 \%$ medio digerido y $23.1 \%$ digerido. Como se observa en la figura 1 , las presas en estado fresco se encontraron en casi todos los meses, excepto marzo en donde todos los estómagos estaban vacíos ( $\mathrm{CV}=100 \%$ ), alcanzando los mayores valores mensuales con excepción de enero $(52.4 \%)$ y septiembre $(36.1 \%)$, donde el estado medio digerido fue el principal. Se destaca 
January $(52.4 \%)$ and September $(36.1 \%)$, where the predominant state was half-digested prey. It is noteworthy that in November there was an absence of half-digested $(0.0 \%)$ and digested states $(0.0 \%)$.

Five prey or food groups were identified: vegetable remains, fishes, detritus, insects and other types, which showed the following annual frequency occurrence: vegetable remains $(63.8 \%)$ was the most common; fishes $(62.7 \%)$ including scales, spines and fins; detritus (43.5\%); insects $(14.1 \%)$ including Hymenoptera, insect rest and Hymenoptera eggs and other types (3.4\%), including snails, worms and nylon. Vegetable remains and rest of fishes were present in every month of the year except March, while detritus was found in every month except March and November, insects were absent in July and November and other types were present in January, May, August and October.

The most abundant item or group was rest of fishes $(34.7 \%)$, which was present every month, followed by vegetable remains $(32.7 \%)$, detritus $(23.1 \%)$, insects $(7.8 \%)$ and other types $(1.7 \%)$. As in the frequency of occurrence, almost all these items were found throughout the year except in November, when no detritus, insects or other types were found. In greater detail, vegetable remains was more abundant in five months of the study, especially in July (48.8\%) and November $(60.0 \%)$; rest of fishes were more abundant in six months of the year, mainly in May (50.0\%); and detritus was more abundant in September $(30.6 \%)$ on par with vegetable remains.

Vegetable remains $(33.5 \%)$ was the most food group with greatest weight composition, followed by detritus $(32.8 \%)$, rest of fishes $(22.3 \%)$, insects $(8.3 \%)$ and other types (3.1\%); being the main food in four months of the year: July $(58.7 \%)$, October $(59.5 \%)$, November $(86.0 \%)$ and December $(44.9 \%)$, while detritus was greater in January, June, August and September (Figure 2).

The gut length-total length relationship (LI-LT) is estimated at 1.1 , which places the species as omnivorous according to the scale proposed by Brusle (11). The correlation between the size of the gut and fish size $(r=0.53)$ is significant at $95 \%$ confidence according to the critical values for the correlation coefficients.

Analyzing food preferences in relation to size, in only three of the intervals (8.5-9.5, 9.5-10.5 and $10.5-11.5 \mathrm{~cm} \mathrm{LT}$ ) consumption of the five food groups (Vegatable remains, rest of fishes, la ausencia de los estados medio digerido (0.0\%) y digerido $(0.0 \%)$ en noviemre.

Se identificaron cinco presas o grupos alimentarios: Material vegetal, peces, detritos, insectos y otros, los cuales mostraron la siguiente Frecuencia de ocurrencia anual: Material vegetal $(63.8 \%)$, el más frecuente; peces $(62.7 \%)$, constituido por escamas, espinas y aletas; detritos $(43.5 \%)$; insectos $(14.1 \%)$, conformado por Hymenoptera, restos de insectos y huevos de Hymenoptera y otros (3.4\%), compuesto por caracol, lombriz y nailon. Material vegetal y restos de peces estuvieron presentes en todos los meses del año, excepto marzo; mientras que detritos se encontró en todos los meses excepto marzo y noviembre; insectos ausente en julio y noviembre y otros, presente en enero, mayo, agosto y octubre.

Restos de peces fue el ítem o grupo más abundante o numeroso (34.7\%), presente en todos los meses del año, seguido por material vegetal $(32.7 \%)$, detritos $(23.1 \%)$, insectos $(7.8 \%)$ y otros $(1.7 \%)$. Al igual que en la Frecuencia de ocurrencia, se encontró a casi todos los ítems presentes durante el año de estudio, con la excepción de noviembre en donde no se encontró detritos, ni insectos, ni otros.. A nivel más detallado, material vegetal fue el más abundante en cinco meses del año de estudio, especialmente en julio (48.8\%) y noviembre $(60.0 \%)$; restos de peces fue el más numeroso en seis meses del año, principalmente en mayo $(50.0 \%)$; y detritos lo fue en septiembre $(30.6 \%)$ a la par con Material vegetal.

Material vegetal (33.5\%) fue el grupo alimentario con mayor composición en peso, seguido por detritos $(32.8 \%)$, restos de peces $(22.3 \%)$, insectos $(8.3 \%)$ y otros $(3.1 \%)$; siendo el

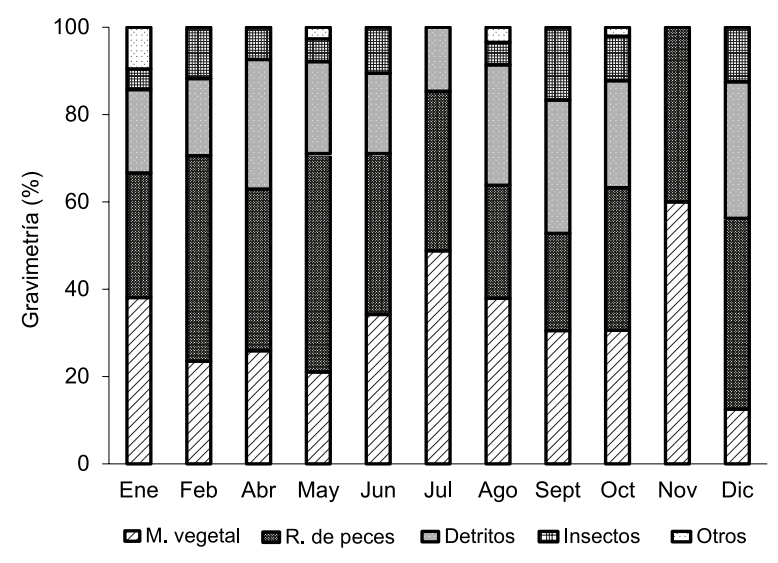

Figure 2. Composition by weight of prey. 
detritus, insects and other types) was found, while at intervals (7.5-8.5, 11.5-12.5 and 12.513.5) other groups were not observed and in the (13.5-14.5) range vegetable remains was not found.

\section{DISCUSSION}

The emptiness coefficient estimated in this study $(39.8 \%)$ is higher than reported for yellow Mojarra Caquetaia kraussii $(29.2 \%)$, from the Cichlidae family in the Urrá dam (12), and which is high for a species that can be considered omnivorous due to the wide trophic spectrum presented. However, this ratio is within the range reported for other cichlids in different areas of South America such as in the Rodo Lake (Uruguay), where Cichlasoma facetum and Gymnogeophagus rhabdotus reached 35.0 and $49.0 \%$, respectively (13).

As for the occurrence of different food groups, similarity was found in the variety but not to the extent shown in this work. Atencio-Garcia et al (12) observed that Caquetaia kraussii fish showed the highest occurrence $(87.1 \%)$ while vegetable remains, other types and insects barely reached $11.3,6.5$ and $1.6 \%$, respectively. In Venezuela, the most frequent groups for $A$. pulcher and $A$. coerulopunctatus were vegetable remains ( 94.0 and $95.0 \%)$, detritus $(90.0$ and $64.0 \%)$, insect larvae (72.0 and $73.0 \%$ ), Coleoptera (26.2 and $32.3 \%$ ) and Copepoda (21.2 and 25.6\%) (14). While, the occurrence of major food groups in Geophagus brasiliensis (Cichlidae) in the Capivari Reservoir in Brazil was fruits and seeds (22.7\%), detritus $(17.9 \%)$, rest of fishes $(10.7 \%)$, Cladocera (7.0\%), Copepoda (6.1\%), Trichoptera (3.9\%) and Chironomidae $(3.9 \%)(15)$.

The abundance of prey found in this work is very different to that reported by other authors for the Cichlidae family in other geographical areas of Colombia and the rest of South America. Fish $(83.3 \%)$, insects $(1.4 \%)$, vegetable remains $(9.7 \%)$ and others $(5.6 \%)$ were the largest groups in the diet of Caquetaia kraussii (12). As for composition by weight, fish $(95.3 \%)$, insects $(1.1 \%)$, vegetable remains $(3.5 \%)$ and others $(0.1 \%)$ were the most important groups in the diet of Caquetaia kraussii (12). Here similarity was not observed between the proportion of trophic groups in the diets of different species, as happened with the frequency of occurrence and numerical frequency.

According to the data obtained in this study, the relative importance index indicates that vegetables rest $(21.4 \%)$, rest of fishes $(14.0 \%)$ and detritus $(14.3 \%)$ have secondary relative importance as food groups, while insects (1.2\%) and other types alimento principal en cuatro meses del año: julio $(58.7 \%)$, octubre $(59.5 \%)$, noviembre $(86.0 \%)$ y diciembre $(44.9 \%)$, mientras que detritos lo fue en enero, junio, agosto y septiembre (Figura 2).

La relación longitud intestinal-longitud total (LI-LT) se estimó en 1.1, lo que ubica a la especie como omnívora, de acuerdo con la escala propuesta por Brusle (11). La correlación entre el tamaño del intestino y la talla del pez $(r=0.53)$ es significativa al $95 \%$ de confianza de acuerdo con los valores críticos para los coeficientes de correlación.

Analizando las preferencias alimentarias con respecto a la talla, en sólo tres de los intervalos (8.5-9.5, 9.5-10.5 y $10.5-11.5 \mathrm{~cm}$ LT) se encontró el consumo de los cinco grupos alimentarios (material vegetal, resto de peces, detritos, insectos y otros), mientras que en los intervalos (7.5-8.5, $11.5-12.5$ y $12.5-13.5)$ no se observó el grupo otros y en el intervalo (13.5-14.5) no se encontró material vegetal.

\section{DISCUSIóN}

El coeficiente de Vacuidad estimado en este trabajo (39.8\%) es mayor al reportado para la Mojarra amarilla Caquetaia kraussii $(29.2 \%)$, especie de la familia Cichlidae en el embalse de Urrá (12), siendo alto para una especie que se puede considerar omnívora debido al amplio espectro trófico que presenta. Sin embargo, este coeficiente se encuentra dentro del rango reportado para otros cíclidos en diferentes áreas de América del Sur como en el lago Rodó (Uruguay), en donde en Cichlasoma facetum y Gymnogeophagus rhabdotus alcanzaron el 35.0 y $49.0 \%$, respectivamente (13).

En cuanto a la ocurrencia de los diferentes grupos alimentarios, se encontró similitud en la variedad de ellos pero no en la proporción arrojada por este trabajo. Atencio-García et al (12) observaron que en Caquetaia kraussii peces mostró la mayor ocurrencia $(87.1 \%)$, mientras que restos vegetales, otros e insectos apenas alcanzaron $11.3,6.5$ y $1.6 \%$, respectivamente. En $A$. pulcher y $A$. coerulopunctatus, en Venezuela, material vegetal (94.0 y $95.0 \%)$, detritos $(90.0$ y $64.0 \%)$, larvas de insectos $(72.0$ y $73.0 \%)$, Coleoptera $(26.2$ y $32.3 \%)$ y Copepoda ( 21.2 y $25.6 \%$ ), fueron los grupos más frecuentes (14). En tanto que la ocurrencia de los principales grupos alimentarios en Geophagus brasiliensis (Cichlidae) en el embalse de Capivari en Brasil, fue: frutas y semillas (22.7\%), detritos $(17.9 \%)$, restos de peces $(10.7 \%)$, Cladocera $(7.0 \%)$, Copepoda $(6.1 \%)$, Trichoptera $(3.9 \%)$ y Chironomidae (3.9\%), (15). 
$(0.1 \%)$ are circumstantial or incidental prey and have low relative importance.

Analyzing the different analysis methods of stomach contents in this work, frequency of occurrence, numerical frequency, gravimetry, as well as the relative importance index (Table 1 ) shows that the food groups most consumed by Cocobolo are

Table 1. Annual values of frequency of occurrence $(O)$, numeric frequency (FN), Gravimetry (G) and Index of relative importance of prey in the stomach of Cocobolo in Ciénaga Grande de Lorica.

\begin{tabular}{lcccc}
\hline Feeding groups & FO (\%) & FN (\%) & G (\%) & IIR (\%) \\
\hline Vegetable remains & 63.8 & 32.7 & 33.5 & 21.4 \\
Rest of fishes & 62.7 & 34.7 & 22.3 & 14.0 \\
Detritus & 43.5 & 23.1 & 32.8 & 14.3 \\
Insects & 14.1 & 7.8 & 8.3 & 1.2 \\
Others & 3.4 & 1.7 & 3.1 & 0.1 \\
\hline Total & & $\mathbf{1 0 0 . 0}$ & $\mathbf{1 0 0 . 0}$ & \\
\hline
\end{tabular}

vegetable remains, rest of fishes and detritus, with an omnivorous diet, preferring fishes and vegetable remains.

Rojas et al (14) reported an omnivorous diet both for the species under study as well as $A$. coeruleopunctatus due to consumption of different resources such as phytoplankton, zooplankton, fish, crustacea, insects (Hemiptera, Odonata and Ephemeroptera) and seeds. Therefore, taking into account issues raised by different authors, agreement is reached about eating habits but not concerning the main feed $(12,14-15)$.

It is observed that in low and rising waters, early and mid-year, the most consumed prey was

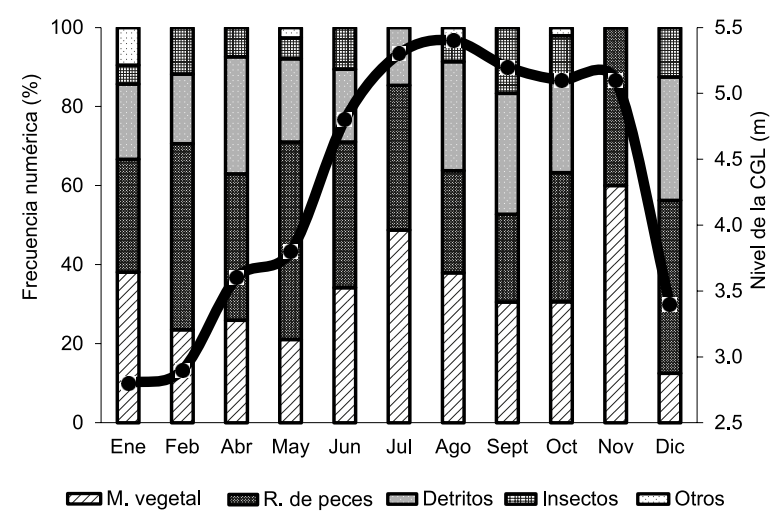

Figure 3. Feeding preferences of Cocobolo and the water cycle in Ciénaga Grande de Lorica.
La abundancia de presas encontrada en este trabajo es muy diferente a la reportada por otros autores para la familia Cichlidae en otras áreas geográficas de Colombia y en el resto de Suramérica. Peces $(83.3 \%)$, insectos $(1.4 \%)$, restos vegetales $(9.7 \%)$ y otros $(5.6 \%)$ fueron los grupos más numerosos en la dieta de Caquetaia kraussii (12). En cuanto a la composición en peso, peces $(95.3 \%)$, insectos $(1.1 \%)$, restos vegetales $(3.5 \%)$ y otros $(0.1 \%)$ fueron los grupos más importantes en la dieta de Caquetaia kraussii (12). Aquí tampoco se observó similitud entre la proporción de grupos tróficos en las dietas de las diferentes especies, tal y como sucedió con la Frecuencia de ocurrencia y la Frecuencia numérica.

De acuerdo con los datos obtenidos en este trabajo, el Índice de importancia relativa indica que material vegetal $(21.4 \%)$, restos de peces $(14.0 \%)$ y detritos $(14.3 \%)$ son grupos alimentarios de importancia relativa secundaria; mientras que insectos $(1.2 \%)$ y otros $(0.1 \%)$ son presas circunstanciales o incidentales y de baja importancia relativa.

Analizando los diferentes métodos de análisis del contenido estomacal utilizados en este trabajo, Frecuencia de ocurrencia, Frecuencia numérica, Gravimetría, además del Índice de importancia relativa (Tabla 1), se observa que los grupos alimentarios más consumidos por el Cocobolo son material vegetal, restos de peces y detritos, y se infiere que su dieta es omnívora, con preferencia por peces y material vegetal.

Rojas et al (14), reportaron una dieta omnívora tanto para la especie en estudio como para $A$. coeruleopunctatus debido al consumo de diferentes recursos, como fitoplancton, zooplancton, peces, crustacea, insectos (Hemiptera, Odonata y Ephemeroptera) y semillas. Por tanto, hay concordancia en torno al hábito alimentario, pero no con el alimento principal, teniendo en cuenta lo planteado por diferentes autores $(12,14-15)$.

Se observó que en aguas bajas y en aguas ascendentes, principios y mediados del año, peces fue la presa más consumida, seguida por material vegetal y detritos, respectivamente; mientras que en aguas altas y aguas descendentes, tercer y cuarto trimestres del año, fueron material vegetal y peces los grupos tróficos más consumidos (Figura 3). La flexibilidad de los hábitos alimentarios es una característica adaptativa del comportamiento animal, una vez que los ambientes naturales varían espacial o temporalmente, y los peces responden a la baja disponibilidad de alimento alterando su comportamiento (16). La mayoría de las especies de peces parecen experimentar un aumento de 
fish, followed by vegetable remains and detritus, respectively. In high and falling waters, third and fourth quarters of the year, vegetable remains and fish were the most consumed trophic groups (Figure 3). Flexible feeding habits are an adaptive feature of animal behavior when the natural environment varies spatially or temporarily, and fish respond to low food availability by altering their behavior (16). Most fish species seem to experience increased competition in shallow waters, which may be a consequence of reduced volumes of water or because flood areas, which provide food and cover in high waters, are not accessible (17), which leads many species to change their feeding preferences during the water cycle (18), as observed in this study.

The results of this study suggest that the Cocobolo has omnivorous feeding habits and a tendency to consume fishes and vegetable remains.

\section{Acknowledgments}

To fishermen and fish traders in Ciénaga Grande de Lorica, lower basin of the Sinú River, and the University of Córdoba for funding received. la competencia en aguas bajas, lo cual puede ser una consecuencia de la reducción del volumen de agua, o que el bosque de inundación, que ofrece alimento y cobertura en el período de aguas altas, no sea accesible (17), por lo que muchas especies también cambian sus preferencias nutricionales durante el ciclo hidrológico (18), tal y como se observó en este trabajo.

Los resultados alcanzados en este estudio sugieren que el Cocobolo es un pez de hábitos alimentarios omnívoros con tendencia a consumir peces y material vegetal.

\section{Agradecimientos}

A los pescadores y comercializadores de pescado de la ciénaga Grande de Lorica, cuenca baja del río Sinú, y a la Universidad de Córdoba por la financiación recibida.

\section{REFERENCES}

1. Musilová Z, Říčan O, Novák J. 2009. Phylogeny of the Neotropical cichlid fish tribe Cichlasomatini (Teleostei: Cichlidae) based on morphological and molecular data, with the description of a new genus. J Zool Syst Evol Res 2009; 47(3):234-247.

2. Olaya-Nieto CW, Arellano Padilla JJ, Martínez González AL. Hábitos alimentarios del Barbul de piedra (Ariopsis sp.) en el río Sinú, Colombia. Acta biol Colomb 2012a; 17(1):117-128.

3. Olaya-Nieto CW, Pacheco-Orozco L, OchoaArteaga J. Hábitos alimenticios del Liso (Rhamdia quelen Quoy \& Gaimard, 1824) en el río Sinú, Colombia. Rev MVZ Córdoba 2012b; 17(3):3217-3223.

4. Maldonado-Ocampo JA, Ortega-Lara A, Usma-Oviedo JS, Galvis G, Villa-Navarro $F A$, Vásquez $L$, et al. Peces de los Andes de Colombia. Bogotá D.C.: Instituto de Investigación de Recursos Biológicos "Alexander Von Humboldt"; 2005.
5. Olaya-Nieto CW, Bautista-Blanco AL, Pérez-Pisciotti M. Biología reproductiva del Cocobolo (Andinoacara pulcher Musilová et al., 2009) (Pisces: Cichlidae) en la ciénaga Grande de Lorica (Córdoba), Colombia. Actual Biol 2010; 32(92):65-73.

6. IGAC, Instituto Geográfico Agustín Codazzi. Estudio General de Suelos y Zonificación de Tierras: departamento de Córdoba, escala $1: 100.000$. Bogotá: Imprenta Nacional de Colombia; 2009.

7. Laevastu T. Manual de métodos de biología pesquera. Zaragoza: Editorial Acribia; 1980.

8. Windell JT. Food analysis and rate of digestion. In: Ricker WE. (ed.). Methods for assessment of fish production in fresh waters. 2nd edition. Oxford: Blackwell Scientific Publications; 1971.

9. Windell JT, Bowen SH. Methods for study of fish diets based on analysis of stomach contents. In: Bagenal T. (ed.). Methods for assessment of fish production in fresh waters. 3rd edition. Oxford: Blackwell Scientific Publications; 1978. 
10. Yáñez-Arancibia A, Curiel-Gómez J, Leyton V. Prospección biológica y ecología del bagre marino Galeichthys caerulescens (Günther) en el sistema lagunar costero de Guerrero, México (Pisces: Ariidae). An Centro Cienc del Mar y Limnol Univ Nal Autón México 1976; 3(1):125-180.

11. Brusle J. Food and feeding in grey mullet. In: Oren $\mathrm{OH}$. (ed.). Aquaculture of grey mullet. Cambridge: Cambridge Univ Press; 1981.

12. Atencio-García VJ, Kerguelén-Durango E, Cura E, Rosado R, Vallejo A, Valderrama M. Régimen alimentario de siete especies ícticas en el embalse de la Hidroeléctrica Urrá (Córdoba, Colombia). Rev MVZ Córdoba 2005; 10(2):614-622.

13. Yafe A, Loureiro M, Scasso F, Quintans F. Feeding of two Cichlidae species (Perciformes) in an hypertrophic urban lake. Iheringia Sér Zool 2002; 92(4):73-79.

14. Rojas JE, Soca LA, García GI. Contenido del tracto digestivo de 4 especies de peces autóctonos y sus implicaciones como biorreguladores de larvas de mosquitos en Venezuela. Rev Cubana Med Trop 2005; 57(3):9-12.
15. Abelha MCF, Goulart E. Oportunismo trófico de Geophagus brasiliensis (Quoy \& Gaimard, 1824) (Osteichthyes, Cichlidae) no reservatório de Capivari, Estado do Paraná, Brasil. Acta Scientiarum Biological Sciences 2004; 26(1):37-45.

16. Balassa GC, Fugi R, Hahn NS, Galina AB. Dieta de espécies de Anostomidae (Teleostei, Characiformes) na área de influencia do reservatório de Manso, Mato Grosso, Brasil. Iheringia Sér Zool 2004; 94(1):77-82.

17. Hawlitschek O, Yamamoto KC, CarvalhoNeto, FGMR. Diet composition of fish assemblage of Lake Tupe, Amazonas, Brazil. Rev Colombiana cienc Anim 2013; 5(2):313-326.

18. Mérona $B$, Rankin-de-Mérona. J. Food resource partitioning in a fish community of the Central Amazonian Floodplain. Neotrop Ichthyology 2004; 2(2):75-84. 